\title{
Litteratur
}

\section{Aage Pilgaard}

Kommentar til Markusevangeliet. Dansk Kommentar til Det nye Testamente 5. Århus: Aarhus Universitetsforlag 2008. 424 s. Kr. 348 (indb.).

Nøjagtig 20 år efter, at Aage Pilgaard udsendte sin første kommentar til Markusevangeliet, foreligger den nu i en helt ny og stærkt forbedret udgave som bind $5 \mathrm{i}$ DKNT. (Forord og forlagsmeddelelse hævder ganske vist, at førsteudgaven kom i 1990, men det er ligesom med piger, der lyver sig yngre; det eksemplar, jeg har, er i hvert fald fra 1988).

Det er mange års beskæftigelse med dette evangelieskrift, der her er sammenfattet, og overblik og en afbalanceret fremstilling betyder, at kommentaren er en fortrinlig lærebog for både begynderen og den mere avancerede læser. Er der kæpheste, bliver de ikke skamridt, og de vist eneste lidt fremmedgørende betegnelser er "evangeliekonstituerende” og "evangeliepersisterende”, som dog forklares i indledningen og i øvrigt ikke optræder særlig tit.

Den obligatoriske indledning er med sine kun 28 sider relativt kort. Først står et afsnit om Markusforskningens metoder. Pilgaard nedtoner det traditionshistoriske aspekt. Hans hovedinteresse er den foreliggende tekst, og hovedsigtet bestemmes som det at kaste lys over dette skrifts teologi i betydningen af den forståelse og forkyndelse af Gud, som netop bringes til udtryk gennem en præsentation af Jesus. Således er dets teologi kendetegnet, kvalitativt ved dens kristologiske karakter, formalt ved dens narrative præsentationsmåde - Pilgaard kalder den "kristologisk-narrativ". Genremæssigt tilhører Mark. biografien, idet det er Jesus-fremstillingen, der er evangeliekonstituerende. Det evangeliepersisterende ligger så i den kognitive funktion, nemlig at indvi disciplene i Jesu vejs indhold og betydning.

Korte afsnit om Markusevangeliets narrative struktur samt det inddragne kildemateriale og dets formbestemmelse leder frem til en udredning af dets baggrund og sigte, der behandles under de tre temaer: Eskatologi, kristologi og ekklesiologi, og med særlige underafsnit om Jesus og templet og om Jesu parusi. Hvad forfatterspørgsmålet angår, taler ifølge Pilgaard ingen afgørende argumenter mod den oldkirkelige overlevering, og tilblivelsen henlægges, hvad tiden angår, til begyndelsen af 70'erne, og med hensyn til stedet regnes Rom for en plausibel hypotese.

Selve fortolkningen er opbygget med en oversættelse, en kort indholdsoversigt (ikke en parafrase) samt en vers for vers eksegese. Det er den græske tekst, der lægges til grund, men kommentaren er skrevet, så den også kan læses af den, der ikke er græskkyndig. Undervejs er 20 særlige emner behandlet i ret kortfattede ekskurser. Det gælder særlige temaer (evangelium, 
Kristus osv.) og baggrundsstof (jødisk faste, spedalskhed osv.). Hele vejen igennem er der et udførligt noteapparat med henvisninger til relevant litteratur, især nyere kommentarer som fx Lars Hartmans. Sidst optræder en fortegnelse over den benyttede litteratur.

Det er virkelig lykkedes at give en fremstilling, der stort set holder sig til denne evangelists teologiske sigte og ikke fortaber sig i spørgsmål om skriftets eventuelle kilder (M. Caseys forsøg på rekonstruktion af evt. aramaiske forlæg fejes ligefrem af uden argumentation), og om hvad der måtte gå tilbage til den historiske Jesus.

En anmelder skal for at dokumentere sin læsning helst også kunne indvende et og andet. Jeg synes således, at temaet "Markusevangeliets brug af Det Gamle Testamente" er underbelyst; der skulle have været en ekskurs; tilmed taler Pilgaard ufortrødent om skriftbevisets centrale kristologiske funktion, men er der overhovedet noget skriftbevis i Markusevangeliet? Det må der i hvert fald argumenteres for. Nogle noter er lidt underlige; det gælder fx henvisningen til S. Ruager s. 299 n. 6 for et tidshistorisk spørgsmål, og s. 379 n. 79 savner jeg en henvisning til Niels Willerts Pilatusbog. Der er velgørende få trykfejl; der er dog enkelte og s. 307 n. 50 skulle de de tolv patriarker have haft hver deres testamente; i hvert fald en enkelt gang er skriftstørrelsen forkert (s. 105-107).

Aage Pilgaard er ikke radikal; hele vejen igennem styrer han en afbalanceret midterkurs. Det er udmærket, ikke mindst når man tager i betragtning, at hans fortolkning, allerede takket være at den er på dansk, vil være den foretrukne lærebog i Markusevangeliet mange år fremover. Og så er den velskrevet og smukt trykt.

Mogens Müller

\section{Kasper Bro Larsen}

Recognizing the Stranger. Recognition Scenes in the Gospel of John. Brill Interpretation Series 93. Leiden: Brill 2008. 265 s. € 99.

Kasper Bro Larsens (KBL) prisbelønnede afhandling genoptager og aktualiserer formkritikkens interesse for genrer og deres Sitz-im-Leben. Bogen indtager den plads, som opgøret med the Hellenism-Judaism Divide har skabt, og placerer det 'jødiske' evangelium i den antikke koinê af en offentlighedskultur, der omfatter såvel de græsk-romerske dramaer som tidens populære romancer. Iflg. KBL kendetegner det en række af disse værker, at fortællingen udfolder sig i spændingsfeltet mellem aktørernes forståelse af begivenhederne (Schein) og en skjult virkelighed (Sein), der unddrager sig hovedpersonernes viden, men som tilskuerne/læserne kan være privilegeret med. Forløsningen sker, når den rette sammenhæng afsløres og erkendes. Mange litterater har brugt scenen fra Odysseus, hvor barnepigen på den fremmedes ar genkender Odysseus, til at gennemtænke afsløringen som paradigme (gr. anagnôrisis). Som genretype er afsløringsscenen særligt egnet til at formidle 